\title{
Observation of recent surges of Vatnajökull, Iceland, by means of ERS SAR interferometry
}

\author{
Andrea FISCHER, ${ }^{1}$ Helmut ROTT, ${ }^{1}$ Helgi BJÖRNSSON ${ }^{2}$ \\ ${ }^{1}$ Institut für Meteorologie und Geophysik, Universität Innsbruck, Innrain 52, A-6020 Innsbruck, Austria \\ E-mail: andrea.fischer@uibk.ac.at \\ ${ }^{2}$ Science Institute, University of Iceland, Dunhaga 3, IS-107 Reykjavik, Iceland
}

\begin{abstract}
Recent surges of two outlet glaciers of the Vatnajökull ice cap, Iceland, were observed using European Remote-sensing Satellite (ERS) synthetic aperture radar (SAR) tandem interferograms from 12 different dates between December 1995 and January 2000. ERS SAR interferometry provided new information on the temporal and spatial variations in surface velocity during surges, after fieldwork became impossible. The area affected by the surge and therefore by increased basal sliding was delineated. The migration of flow divides on the ice cap during a surge was described. At Sylgjujökull, a western outlet glacier covering an area of $175 \mathrm{~km}^{2}$, the fully developed surge and its abating phase were studied. Over a period of $>2$ years after December 1995, the ice motion decreased steadily, with initially the highest velocities and subsequently the most pronounced decrease in velocity at the glacier terminus. The surge of Dyngjujökull, a northern outlet glacier covering an area of $1040 \mathrm{~km}^{2}$, reached its maximum in 1999/2000. Slow acceleration over an area of about $200 \mathrm{~km}^{2}$ was first observed between March 1996 and January 1997. The interferogram from January 1999 shows a well-developed surge area, covering $210 \mathrm{~km}^{2}$. This area more than doubled by January 2000, with maximum velocities reaching $>7 \mathrm{~m} \mathrm{~d}^{-1}$. Between January 1997 and January 2000, the flow divide between Dyngju- and Skeiðarárjökull shifted $16 \mathrm{~km}$ to the south. The investigations indicate that a surge cycle on these glaciers spans several years, with slowly increasing motion over an extended area in the beginning, and more pronounced velocity changes during the active surge phase lasting $1-2$ years.
\end{abstract}

\section{INTRODUCTION}

The large, lobate southwestern, western and northern outlets of the Vatnajökull ice cap in Iceland tend to surge, with a typical active surge phase of 1-2 years (Thórarinsson 1969; Björnsson and others, 2003). Recently, surges caused advances by Skeiðarárjökull (1991), Siðujökull (1994), Tungnaárjökull (1994), Sylgjujökull (1996) and Dyngjujökull (1999). We utilized satellite-borne synthetic aperture radar (SAR) imagery to study the velocity field and extent of the surges of Sylgju- and Dyngjujökull with interferometric techniques at different stages of these events.

Surges of temperate glaciers are considered to occur when normal rapid drainage through the subglacial tunnel system is disrupted and a distributed linked drainage system, which facilitates sliding, forms (Kamb, 1987; Raymond, 1987). A surge may be triggered after steepening of the glacier because the net mass balance in the upper part of the glacier is only partly transported downstream during the quiescent period.

Previous studies of surges of Vatnajökull were carried out by Thórarinsson (1964, 1969), Björnsson (1998) and Björnsson and others (2003). SAR interferometric work at Vatnajökull focused on studies of ice deformation after the Gjálp subglacial volcanic eruption in 1996 (Jónsson and others, 1998; Alsdorf and Smith, 1999; Björnsson and others 2001). The eruption had no apparent impact on the surges. Nevertheless, for clarification, the location of that eruption is denoted in Figures 2 and 4 , since the inflow into the volcanic fissure produces some motion fringes, which are not related to any surge event.
Various other surges have been studied by means of SAR interferometry (e.g. the surges of Bering Glacier, Alaska, U.S.A. 1993-95 (Fatland, 1998; Fatland and Lingle, 1998); Ryder Glacier, Greenland (Joughin and others, 1996b); and Monacobreen, Spitsbergen, Svalbard (Strozzi and others, 2000)).

\section{INTERFEROMETRIC PROGESSING}

The investigations are based on repeat-pass synthetic aperture radar (SAR) data of the European Remote-sensing Satellites ERS-1 and -2. The phase shift in the interferograms, calculated from two complex SAR images, is related to changes in the geometric path length of the radar signal between satellite and surface, $\Delta R$, and differences in the optical path through the atmosphere (Massonnet and Feigl, 1998; Rosen and others, 2000; Hanssen, 2001). The atmospheric phase term can be eliminated over surfaces with steady or no motion by processing time series of images. During the course of a glacier surge, surface topography and motion change simultaneously, so the atmospheric phase term could not be removed with this method. From atmospheric signals in the flat ice-free areas surrounding the glacier, it can be concluded that atmospheric phase shifts in the available interferograms are less than half a fringe at scales of several kilometres to tens of kilometres. Therefore, the atmospheric noise is of little relevance for this study.

Excluding atmospheric propagation effects, the path 


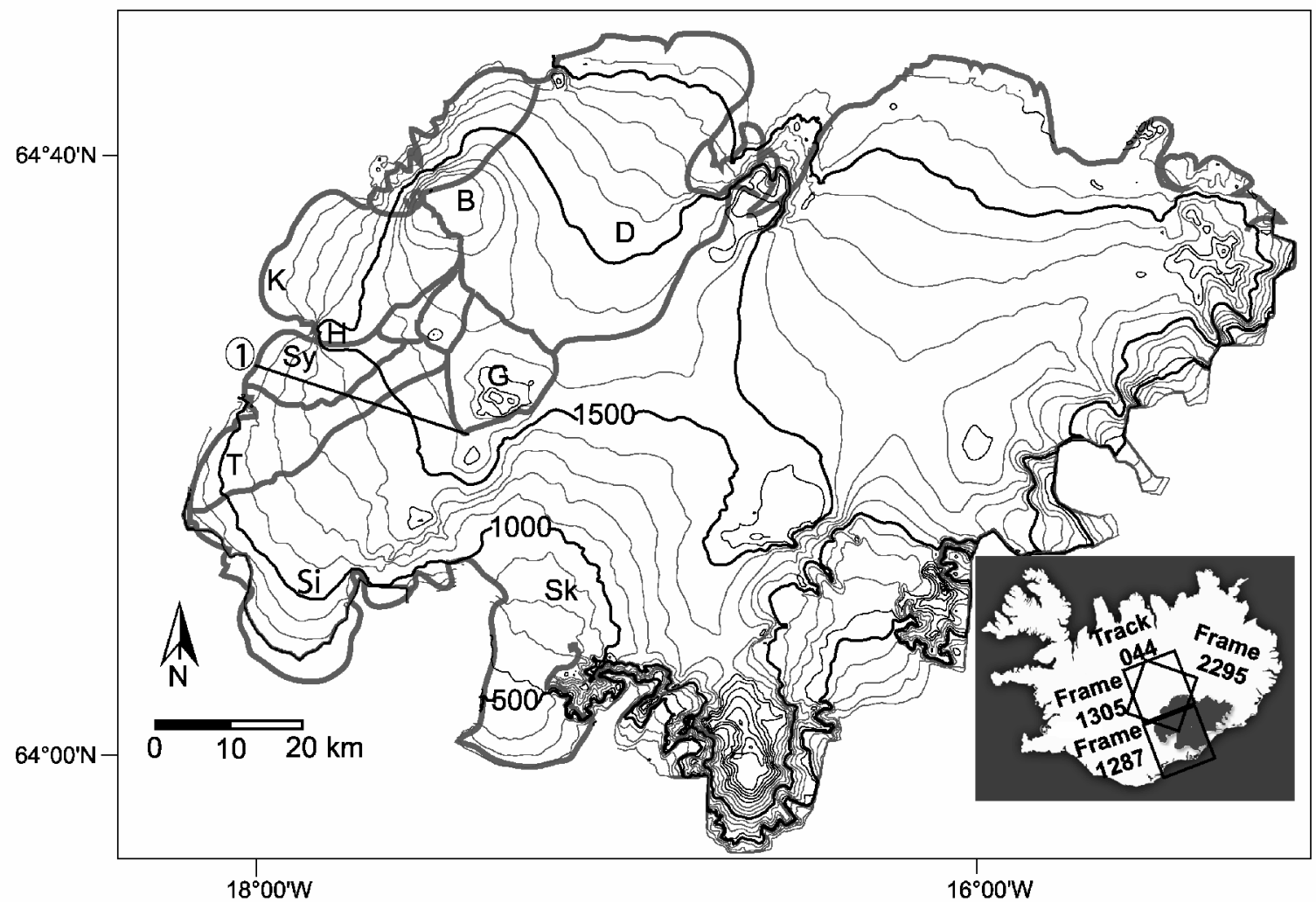

Fig. 1. Site map of Vatnajökull with 100 m elevation contours and selected flow divides (grey lines) (after Björnsson and others, 1998). The inset shows the position of the SAR scenes. B, Bárðarbunga; D, Dyngjujökull; G, Grimsvötn; H, Hamarinn; K, Köldukvíslarjökull; Sk, Skeiðarárjökull; Si, Siðujökull; Sy, Sylgjujökull; T, Tungnaárjökull. 1. The black line at Sylgjujökull denotes the position of the profile shown in Figure 3.

changes, $\Delta R$, represent the sum of the path variations due to (i) variations of the incidence angle across the swath on the flat Earth, (ii) topography, and (iii) displacement of the surface in the line of sight (LOS) of the radar beam. Whereas terms (i) and (ii) depend on the distance between the antenna positions

Table 1. Analyzed ERS SAR tandem interferograms with perpendicular component of the baseline $B_{\text {perp }}$ and height of mabiguity $H_{\mathrm{a}}$ in scene centre

\begin{tabular}{|c|c|c|c|c|c|}
\hline Frame & Track & Asc./Des. & Date & $\begin{array}{c}B_{\text {perp }} \\
\mathrm{m}\end{array}$ & $\begin{array}{r}H_{\mathrm{a}} \\
\mathrm{m}\end{array}$ \\
\hline 1287 & 44 & Asc. & 13/14 Dec. 1995 & 162 & 61 \\
\hline 1287 & 44 & Asc. & 27/28 Mar. 1996 & 12 & 762 \\
\hline 1287 & 44 & Asc. & 23/24 Oct. 1996 & 73 & 134 \\
\hline 1287 & 44 & Asc. & 1/2 Jan. 1997 & 253 & 43 \\
\hline 1287 & 44 & Asc. & 12/13 Mar. 1997 & 59 & 166 \\
\hline 1287 & 44 & Asc. & 21/22 Мay 1997 & 40 & 237 \\
\hline 1287 & 44 & Asc. & 17/18 Dec.1997 & 240 & 42 \\
\hline 1287 & 44 & Asc. & 6/7 Jan. 1999 & 124 & 80 \\
\hline 1287 & 44 & Asc. & 10/11 Feb. 1999 & 113 & 86 \\
\hline 1287 & 44 & Asc. & 26/27 Jan. 2000 & 73 & 133 \\
\hline 1305 & 44 & Asc. & 13/14 Dec. 1995 & 160 & 61 \\
\hline 1305 & 44 & Asc. & 27/28 Mar. 1996 & 11 & 874 \\
\hline 1305 & 44 & Asc. & 1/2 Jan. 1997 & 225 & 44 \\
\hline 1305 & 44 & Asc. & 21/22 May 1997 & 41 & 241 \\
\hline 1305 & 44 & Asc. & 17/18 Dec. 1997 & 232 & 42 \\
\hline 1305 & 44 & Asc. & 6/7 Jan. 1999 & 113 & 87 \\
\hline 1305 & 44 & Asc. & 10/11 Feb. 1999 & 109 & 89 \\
\hline 1305 & 44 & Asc. & 26/27 Jan. 2000 & 70 & 139 \\
\hline 2295 & 9 & Des. & 29/30 Apr. 1996 & 71 & 138 \\
\hline 2295 & 9 & Des. & 21/22 Oct. 1996 & 125 & 78 \\
\hline
\end{tabular}

of the two images (the baseline), the displacement-related phase, $\phi_{\text {dis }}$, is independent of the baseline. The flat-Earth contribution can be calculated from precise satellite orbit data and/or ground-control points. For most of the images, we used the precise orbit data of the Delft Institute for Earth-Oriented Space Research (DEOS) (Scharroo and Visser, 1998). A firstorder correction of the orbit parameters was carried out using control points.

After subtracting the flat-Earth phase, it is necessary to separate the topographic phase, $\phi_{\text {topo }}$, and the displacement term, $\phi_{\text {dis }}$. The separation of the two phase terms by means of differential interferometry (Joughin and others, 1996a) was not applied in this study, since the assumption of steady motion is not valid during the surges. The topographicphase images were computed from external data: the precise orbit data and a digital elevation model (DEM) of the glacier. The DEM of Dyngjujökull was produced by the Science Institute of the University of Iceland in 1989 and has an estimated vertical accuracy of $2-5 \mathrm{~m}$; the DEM of Sylgjujökull dates from 1980 and has an estimated accuracy of $10 \mathrm{~m}$. The arbitrary constant of the absolute phase was determined using a least-squares fit to three non-moving targets and three stake velocities which showed small seasonal and annual changes.

For the interpretation of the interferometric data in terms of surface displacement, it is necessary to consider the sensitivity of the phase to artefacts introduced by errors of the DEM, which can be significant in the case of surges if the DEM is not updated. The sensitivity to topography (and to height errors of the DEM) is directly related to the altitude of ambiguity, $H_{\mathrm{a}}$, which corresponds to the elevation difference for one fringe and depends on the interferometric baseline. In half of the available interferograms the sensitivity to 

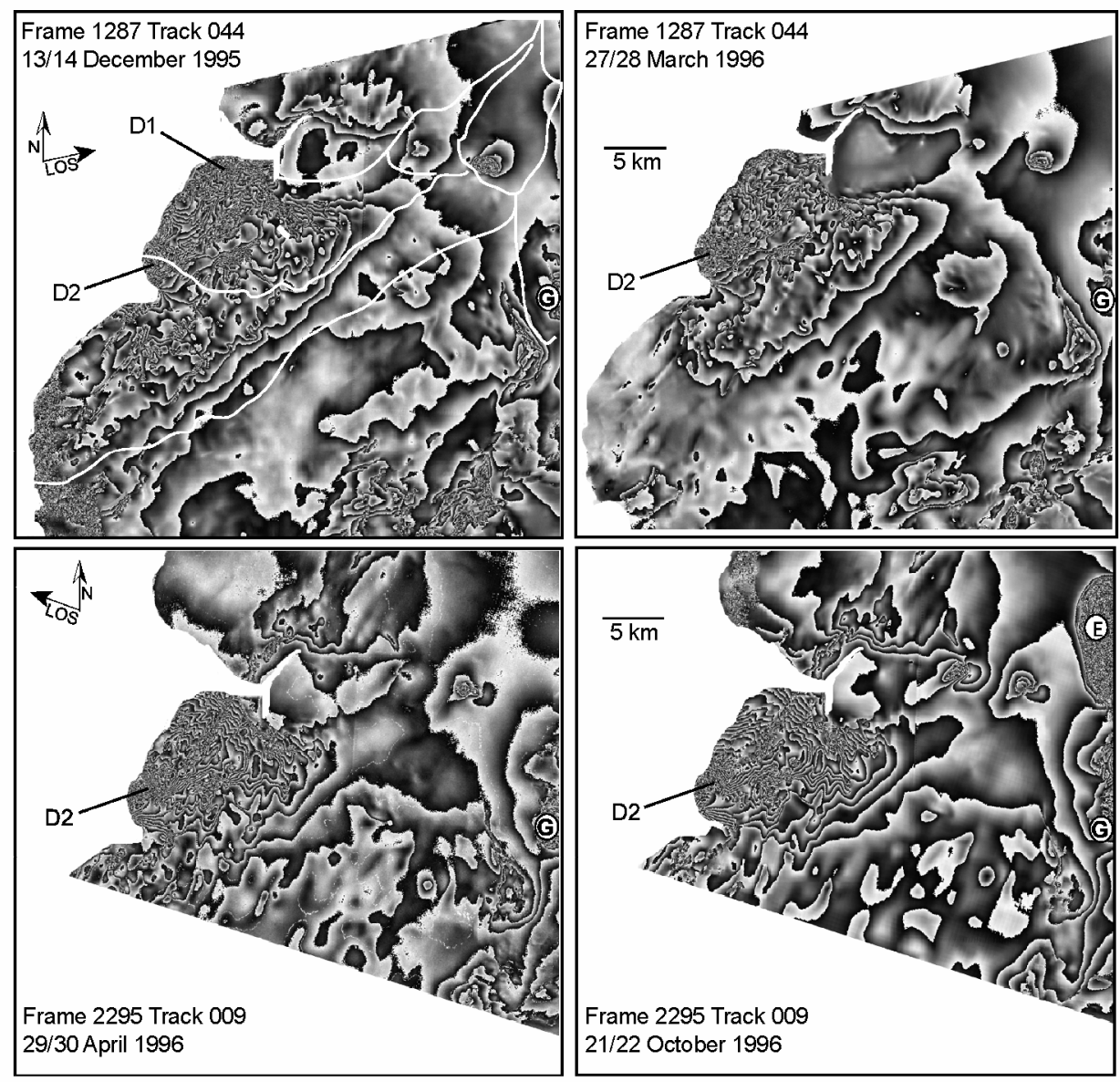

Fig. 2. Geocoded wrapped interferometric motion phase at Sylgjujökull from ERS SAR data of 13/14 December 1995, 27/28 March 1996 (both ascending orbit), 29/30 April 1996 and 21/22 October 1996 (both descending orbit). Arrows show north and radar LOS. Solid white lines are flow divides after Björnsson (1988). G, Grimsvötn; E, eruption site.

topography is quite small $\left(H_{\mathrm{a}} \geq 130 \mathrm{~m}\right)$, whereas in the four most sensitive cases $H_{\mathrm{a}}$ is about $40 \mathrm{~m}$ (Table 1). A phase shift of $2 \pi$ (one fringe) corresponds to a LOS displacement $\Delta R=$ $2.83 \mathrm{~cm}$. So, for example, an error in surface height of $30 \mathrm{~m}$, which can occur in the course of a surge, would cause an error in displacement of $0.6 \mathrm{~cm}$ if $H_{\mathrm{a}}=130 \mathrm{~m}$. Changes of the glacier surface on Vatnajökull due to precipitation, melt and wind cause fast decorrelation of the signal. Therefore, only ERS-1 and -2 tandem data separated by 1 day show sufficient coherence for interferometric processing (Rott and Siegel, 1998). For this study, 18 tandem pairs from ascending orbit and two pairs from descending orbit, acquired between December 1995 and January 2000, were used (Table 1).

In order to assist in the interpretation of the interferometric data, the direction of radar illumination (LOS) is shown in the figures. The interferometric sensitivity to motion is zero along track, while the sensitivity to displacement in the vertical $(z)$ and in ground range $\left(r_{\mathrm{g}}\right.$, horizontal, across track) depends on the incidence angle, $\theta$, of the radar beam according to

$$
\Phi_{\mathrm{dis}}=\frac{4 \pi}{\lambda} \Delta R=\frac{4 \pi}{\lambda}\left(r_{\mathrm{g}} \sin \theta-z \cos \theta\right) .
$$

ERS SAR, with $19^{\circ} \leq \theta \leq 26^{\circ}$, is about twice as sensitive to vertical motion as to horizontal motion. Because the direction of ice motion during surges is not known in detail, the LOS displacement is in general used in this study. In addition, the assumption of (pre-surge) surface-parallel motion in the direction of maximum slope is used for providing estimates of the surface velocities. Where this assumption is used, it is explicitly stated in the text.

\section{THE SURGE OF SYLGJUJÖKULL, 1995/96}

Sylgjujökull, one of the western outlet glaciers, covers an ice drainage area of $175 \mathrm{~km}^{2}$ and extends over a length of $20 \mathrm{~km}$ between 1650 and $880 \mathrm{~m}$ a.s.l. (Fig. 1). The bedrock of Sylgjujökull includes two mountain ridges striking parallel in a northeasterly direction towards Hamarinn. A cone-shaped volcano, which rises above $1000 \mathrm{~m}$ a.s.l., is situated on the first of these ridges (Björnsson, 1988). The mean ice thickness is about $325 \mathrm{~m}$, resulting in an ice volume of $41 \mathrm{~km}^{3}$. The average altitude of the equilibrium line is at approximately $1150 \mathrm{~m}$ a.s.l. (Björnsson and others, 1998).

An increased flow velocity was observed during summer 1995 at $1100-1200$ ma.s.l. before new crevasses prevented further measurements of stake velocities. In 1996, the surge reached the terminus and the glacier started to advance, which is the state shown in our first interferograms. Because of dangerous crevasses, the fieldwork was not resumed until 2002.

Two tandem interferograms (topographic component removed) from ascending and two from descending orbits, acquired between December 1995 and October 1996, show the final stage of the active surge phase on Sylgjujökull (Fig. 2). The interferograms of the descending orbit are more sensitive to surface motion than those of the ascending orbit, because of the smaller relative angle between the ice motion vector and the radar beam. The interferogram of 13/14 December 1995 


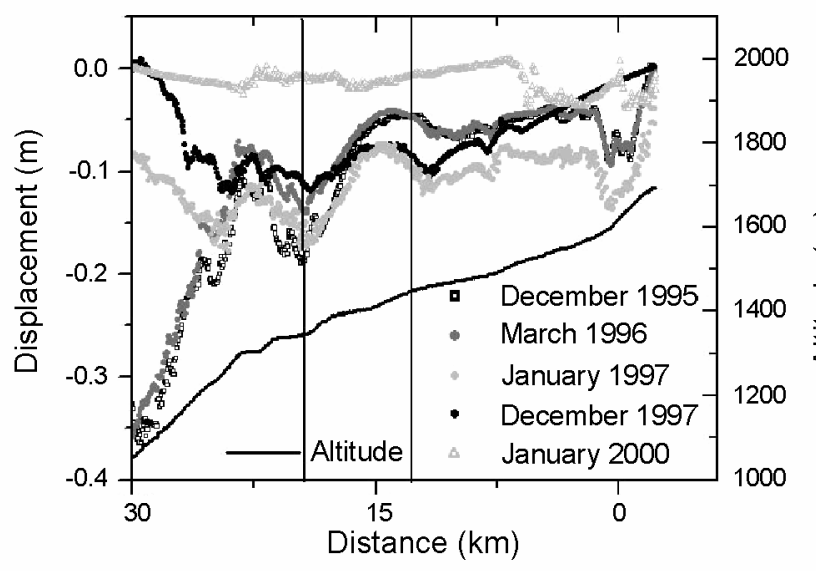

Fig. 3. Profiles of 1 day LOS displacement at Sylgjujökull from interferograms of ascending orbits (13/14 December 1995, 27/28 March 1996, 1/2 January 1997, 17/18 December 1997, 26/27 January 2000). The black line showes the topography of the profile.

(Fig. 2) shows an area of about $60 \mathrm{~km}^{2}$ of high LOS displacement rates $\left(>0.1 \mathrm{~m} \mathrm{~d}^{-1}\right)$. The signals decorrelate in two small sections at the southern and the northern margin (D1 and D2) because of very high velocities, which lead to high velocity gradients over a comparatively small region and possibly also to changes in the surface structure. The region of rapid motion is surrounded by a larger area of accelerated or disturbed flow, covering about $300 \mathrm{~km}^{2}$, with LOS displacement rates $>0.05 \mathrm{~m} \mathrm{~d}^{-1}$. The maximum LOS motion we could measure is $0.45 \mathrm{~m} \mathrm{~d}^{-1}$, which corresponds to an ice velocity of $2.4 \mathrm{~m} \mathrm{~d}^{-1}$ under the surface-parallel assumption (SPA).

About 3 months later, on 27/28 March 1996, the area of rapid motion was nearly the same $\left(66 \mathrm{~km}^{2}\right)$, whereas the area of accelerated flow had decreased $\left(250 \mathrm{~km}^{2}\right)$. At D1 the fringes are clearly visible, which suggests deceleration since December 1995. The maximum motion is observed near the front, with $>0.34 \mathrm{~m} \mathrm{~d}^{-1}$ in LOS, corresponding to $1.5 \mathrm{~m} \mathrm{~d}^{-1}$ under the SPA. The first interferogram from a descending orbit was acquired on 29/30 April 1996, where the maximum shift is about $0.57 \mathrm{~m} \mathrm{~d}^{-1}$ in LOS, corresponding to $1.3 \mathrm{~m} \mathrm{~d}^{-1}$ under the SPA.

Half a year later, in the interferogram of 21/22 October 1996, the maximum LOS displacement rate had decreased to $0.48 \mathrm{~m} \mathrm{~d}^{-1}$ near the terminus $\left(1.15 \mathrm{~m} \mathrm{~d}^{-1}\right.$ under the SPA). The margins of the area of high displacement rates were about the same.

In all four interferograms, the area of fast ice flow $\left(>0.1 \mathrm{~m} \mathrm{~d}^{-1}\right)$ is not confined to the basin of Sylgjujökull as defined before the start of the surge (Björnsson, 1988), but
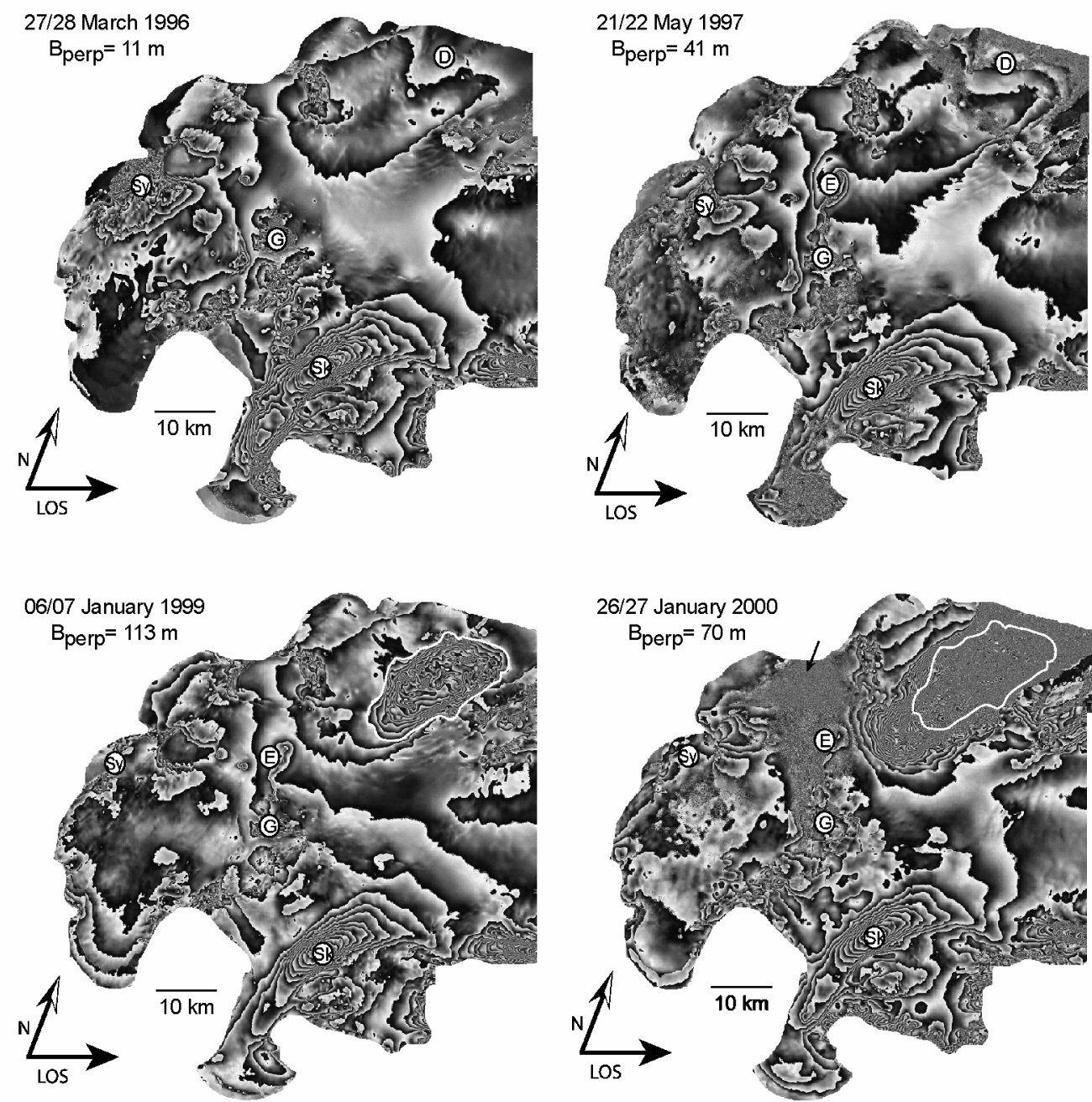

Fig. 4. Wrapped interferometric LOS motion phase (ascending orbit, frame 1287 and 1305, track 44) from 27/28 March 1996, 21/ 22 May 1997, 6/7 January 1999 and 26/27 January 2000. The north direction and the LOS of the satellite are indicated by arrows. D, Dyngjujökull; E, location of the volcanic eruption; G, Grimsvötn; Sk, Skeiðarárjökull; Sy, Sylgjujökull. The white line surrounds the area of fast flow of the January 1999 interferogram. 

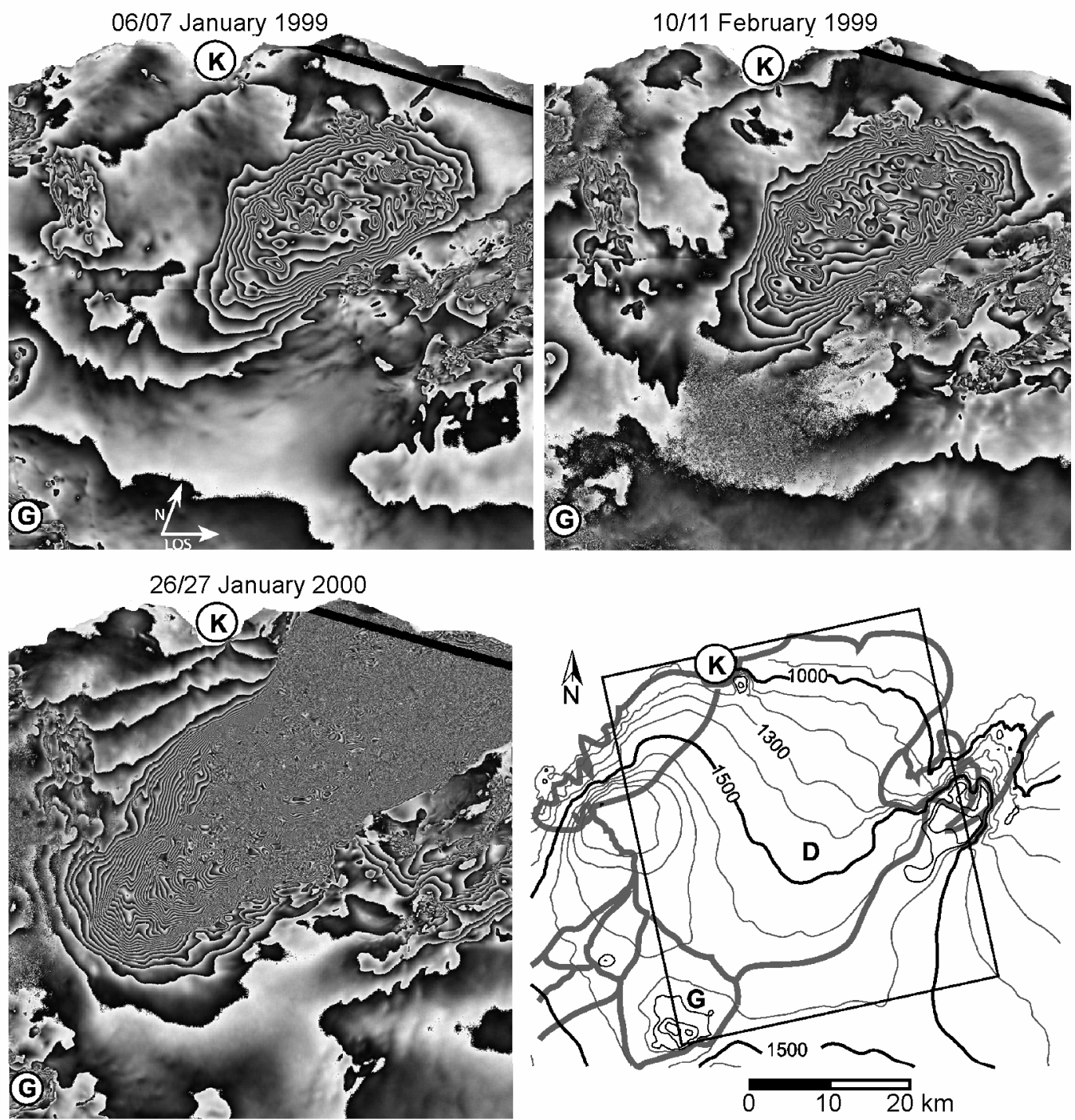

Fig. 5. Wrapped motion-only interferograms of Dyngjujökull from Fanuary 1999, February 1999 and Fanuary 2000. The map shows the location of the interferograms. The black line in the interferograms shows the margin of the DEM used for the computation of the synthetic topographic phase. The flow divides given by Björnsson (1998) are indicated by the grey lines. D, Dyngjujökull; G, Grimsvötn; K, Kistufjell.

extends to Tungnaárjökull (Fig. 2). The interferograms of December 1995 and March 1996 (ascending orbit) do not show a significant decrease in the area of fast flow over the intervening time, but do show a decrease in the highest velocities. Over the period April 1996-October 1996 (descending orbit), the area showing fast flow decreased, and further deceleration was observed.

The temporal change of the ice flow between December 1995 and January 2000 along a profile extending from the front of Sylgjujökull to Grímsvötn (Fig. 1) is shown for five highly coherent tandem interferograms (Fig. 3). The maximum velocities in December 1995 and March 1996 were located near the snout; upstream the velocity decreased to a first minimum located at about $\mathrm{km} 22$ of the profile. In January 1997, the maximum velocity occurred at $\mathrm{km} \mathrm{25,}$ $5 \mathrm{~km}$ upstream from the terminus, where the velocity had decreased to $0.17 \mathrm{~cm} \mathrm{~d}^{-1}$ in LOS. By December 1997 the motion had approached zero at the front, and the variations of velocity along the profile were already largely smoothed out. The very low velocities in January 2000 along the whole profile confirm that the surge had ended some time before.

The upper section of the profile in Figure 3 (right side of the profile) belongs to the upper part of the accumulation area of Síðujökull. The increased motion in December 1995, March 1996 and January 1997 may be a reaction to the surge of Síðujökull (1993/94).

\section{THE SURGE OF DYNGUJÖKULL, 1999/2000}

Dyngjujökull is a northern outlet glacier of Vatnajökull, drained by the river Jökulsá á Fjöllum (Fig. 1). The ice drainage basin covers an area of $1040 \mathrm{~km}^{2}$, and the glacier length is $45 \mathrm{~km}$, with a height of 730-1990 m a.s.l. The equilibriumline altitude varied between $1100 \mathrm{~m}$ a.s.l. (1992/93) and $1385 \mathrm{~m}$ a.s.l. (1997/98). A high accumulation-area ratio of about 0.75 was observed for the mass-balance year 1991/92. Dyngjujökull is the only glacier of Vatnajökull which had a positive net balance in all the years 1991-95 (Björnsson and others, 1998). The ice velocity measured in the years 1993-95 was much lower than the required balance velocity.

The motion of Dyngjujökull was analyzed using interferograms from 27/28 March 1996 and 21/22 May 1997, before the onset of the surge, and three interferograms acquired during the active phase on 6/7 January 1999, 10/11 February 1999 and 26/27 January 2000, all acquired from the ascend- 


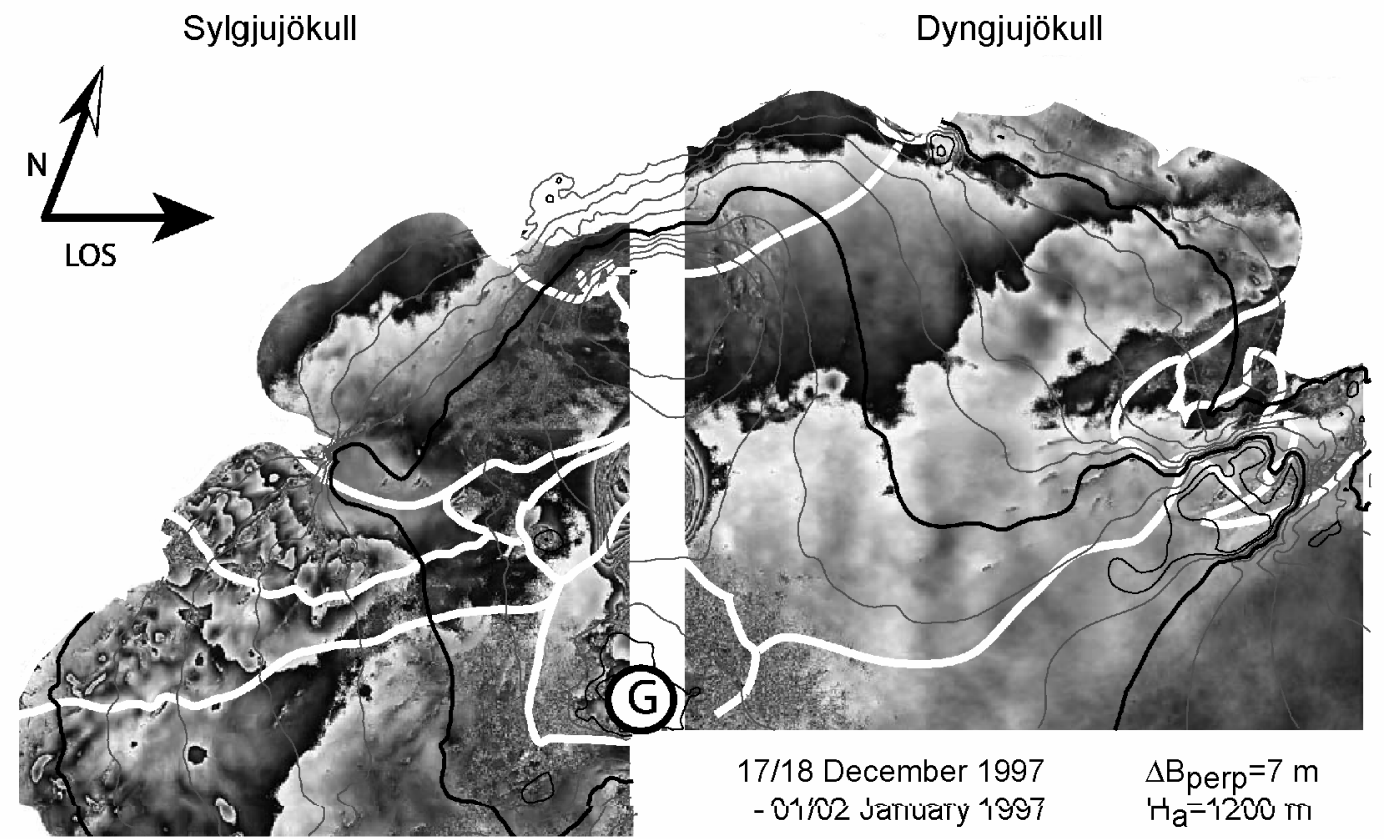

Fig. 6. Phase difference between 17/18 December 1997 and 1/2 Fanuary 1997. North and LOS are indicated by arrows. The subsets showing Sylgju- and Dyngjujökull are chosen according to Figures 2 and 5. G, Grimsvötn.

ing orbit (Figs 4 and 5). On 27/28 March 1996, the surge of Sylgjujökull was still ongoing (Sy in Fig. 4), and Skeiðarárjökull also showed more rapid motion in 1996 and 1997 than in the following years (Sk in Fig. 4). On the northern part of the ice cap, no significant velocities are observed in the two earlier interferograms. The LOS displacement on the terminus of Dyngjujökull was around $0.03 \mathrm{~m} \mathrm{~d}^{-1}\left(0.07 \mathrm{~m} \mathrm{~d}^{-1}\right.$ under the SPA) in March 1996. About 14 months later, in May 1997, the LOS velocity had increased to $0.08 \mathrm{~m} \mathrm{~d}^{-1}\left(0.2 \mathrm{~m} \mathrm{~d}^{-1}\right.$ under the SPA).

In January 1999, an extensive area of accelerated flow is visible at Dyngjujökull (surrounded by the white line in Fig. 4). Additional motion fringes appear between Skeiðarárjökull and Dyngjujökull, in an area with very low displacement rates in the interferograms from 1996 and 1997. Between 6/7 January 1999 and 10/11 February 1999, the area of fast flow increased from about $210 \mathrm{~km}^{2}$ to $250 \mathrm{~km}^{2}$ (Fig. 5). In the interferogram of 26/27 January 2000 the area affected by the surge is $550 \mathrm{~km}^{2}$, and the upper margin of the surge area has shifted about $20 \mathrm{~km}$ towards the southwest since February 1999.

The interferometric motion phases at Dyngjujökull are shown in detail in Figure 5. In January and February 1999, the individual fringes can be clearly discriminated in the surge area, revealing a complex pattern with a number of dense concentric fringe structures (bull's-eyes). These correspond to local maxima of LOS motion, which are probably caused by an increased vertical component of motion. The maximum LOS motion is found near the equilibrium line at about $1300 \mathrm{~m}$ a.s.l. The positions of the bull's-eyes remain stable over the 5 week interval, and the LOS displacement rates reach $0.4 \mathrm{~m} \mathrm{~d}^{-1}$ within these features. This would correspond to a pure vertical displacement of 0.43 or $1.00 \mathrm{~m} \mathrm{~d}^{-1}$ under the SPA. Between January and February 1999, the displacement rate increased on average by about $20 \%$. The western part of the glacier, which seemed to be undisturbed in the interferograms up toJanuary 1999, also showed a moderate speed-up during this time. In 1999, field observations showed that the crevassed area had expanded up to
$1600 \mathrm{~m}$ a.s.l., and in June a bulge migrated down-glacier until it reached the terminus in November.

In January 2000 the velocity could not be retrieved by means of interferometry over the main part of the surging area because of decorrelation caused by high deformation rates. By means of speckle tracking (Gray and others, 2000), the motion was derived for a large part of the glacier. Surface velocities of up to $7 \mathrm{~m} \mathrm{~d}^{-1}$ were measured with this method. In the areas with the highest velocities, the surface changed drastically during a day, so that even speckle tracking could not be applied to derive the velocities.

In contrast to the interferograms of January and February 1999, in which the maximum velocity is located near the equilibrium line, the maximum velocity in the interferogram of January 2000 is located near the snout. This corresponds to the location of the maximum velocity during the most active phase of the surge of Sylgujökull in December 1995 and March 1996.

The results agree well with the field measurements. The ice velocity was much lower than the required balance velocity in the years 1993-95. In 1996, the first signs of increased sliding were observed at 1200-1400 ma.s.l., which corresponds approximately to the state of the glacier in our first interferogram. In 1997, crevasses opened in the 1200-1400 m elevation area. Sliding increased significantly and the crevasses widened in 1998, and the fieldwork ended in 1999.

\section{DIFFERENTIAL ANALYSIS OF MOTION, JANUARY- DECEMBER 1997}

The interferograms from 1/2 January 1997 and 17/18 December 1997 (track 44, frames 1287 and 1305) have very similar baselines. Differencing of these two interferograms can reveal temporal changes of surface motion. The phase differences on western Vatnajökull between these two interferograms are shown in Figure 6. This image presents differential phase shifts due to different displacement rates on the two dates and a small topographic contribution with a height of ambiguity of 


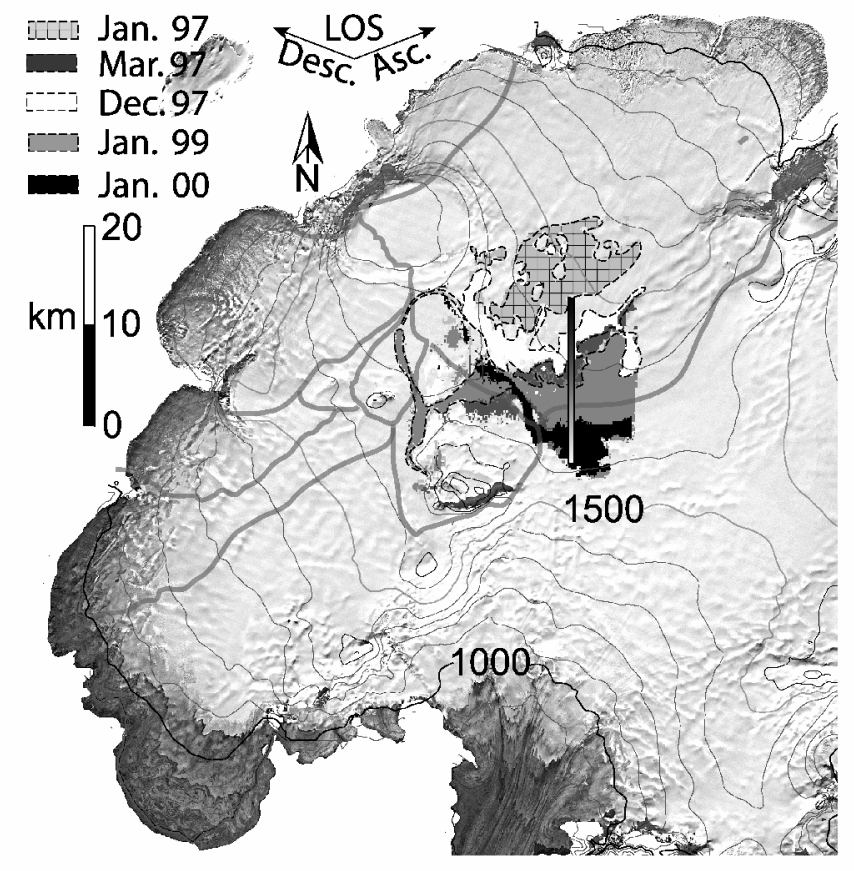

Fig. 7. Areas with displacement rates $<1 \mathrm{~cm}^{-1}$ between Fanuary 1997 and January 2000 for different dates. The north direction and the look directions are indicated by arrows. The contour levels are shown in thin grey lines; the thick grey lines correspond to the flow divides according to Björnsson (1988). The shaded bar shows the migration of the southern margin of the divide zone by $16 \mathrm{~km}$ between Fanuary 1997 and Fanuary 2000.

$1200 \mathrm{~m}$. The atmospheric noise is probably small because the water-vapour content, the main disturbing factor, is low in winter. Changes in topography between the data acquisitions would show up with an altitude of ambiguity of $42 \mathrm{~m}$; but during the year 1997, the changes of surface height were small compared to this value except in the region of Gjálp.

Temporal changes of surface motion are evident on various parts of the ice cap. On Sylgjujökull the ice velocity was still decreasing after the surge, with an average difference of $0.09 \mathrm{~m} \mathrm{~d}^{-1}$ LOS between January and December 1997. On Dyngjujökull, the LOS displacement rate increased by about $0.01-0.02 \mathrm{~m} \mathrm{~d}^{-1}$ homogeneously over the area where the surge began 1 year later.

\section{MIGRATION OF FLOW DIVIDES}

SAR interferometry enables ice-flow divides to be located, though some constraints have to be taken into account. At a flow divide, the horizontal ice velocity is zero and the vertical velocity of a particle at the surface is approximately equal to the net mass-balance rate (Paterson, 1994). The net mass balance over 1 day, under conditions in which the radar signal remains coherent, is very close to zero, as is the vertical velocity at the flow divide. However, zero LOS displacement in an interferogram can also result if the ice flows horizontally in the along-track direction of the satellite, or if the phase contributions of the vertical and the horizontal velocity compensate each other. For the latter, the vertical velocity must be approximately half of the ground range velocity and of opposite sign. Further, because some residual phase noise must be taken into account, it is not possible to use the sharp definition of zero velocity to infer the position of flow divides. We used a relaxed threshold of $0.01 \mathrm{~m} \mathrm{~d}^{-1}$ to estimate the approximate position of flow divides, which leaves some room for phase noise. The standard deviation of the displacement rate within the areas identified as flow divides with this method ranges from $0.0050 \mathrm{~m} \mathrm{~d}^{-1}$ in January 2000 to $0.0021 \mathrm{~m} \mathrm{~d}^{-1}$ in January 1999. Areas where the direction of ice flow is close to the satellite ground track were excluded.

Figure 7 shows the temporal evolution of areas with near-zero motion at Dyngjujökull, providing an indication of the position of flow divides, obtained from interferograms of 1/2 January 1997, 12/13 March 1997, 17/18 December 1997, 6/7 January 1999 and 26/27 January 2000. The western part of Dyngjujökull is not covered by the data used for this analysis, so no flow divides are shown there. From January 1997 to January 2000, the flow divide migrated continuously to the south. The March 1997 interferogram shows the divide about $0.5 \mathrm{~km}$ further south than the December 1997 interferogram. This might possibly be related to seasonal variation in the ice flow. Between January 1997 and January 2000, the flow divide between Dyngju- and Skeiðarárjökull shifted by about $16 \mathrm{~km}$ to the south.

Concurrent with the shift of the flow divide southward and the decrease of the accumulation area, the velocity on Skeiðarárjökull decreased significantly. The maximum LOS displacement, located several kilometres above the firn line, decreased from $0.35 \mathrm{md}^{-1}$ in March 1996 to $0.10 \mathrm{~m} \mathrm{~d}^{-1}$ in January 2000.

\section{SUMMARY AND GONGLUSIONS}

Interferograms obtained from ERS SAR data provided maps of ice motion on Vatnajökull, enabling a study of spatial patterns of ice dynamics and their temporal evolution. A precondition for the application of interferometry over these glaciers is that the SAR imaging occurs over a short time-frame; this limits the useful dataset to ERS-1/-2 tandem pairs available for several dates between December 1995 and January 2000.

Surges of two major outlet glaciers, Sylgjujökull and Dyngjujökull, were imaged at different stages. The interferograms from Dyngjujökull cover the pre-surge phase up to the full development. The LOS ice velocities prior to the surge were only about $1-2 \mathrm{~cm} \mathrm{~d}^{-1}$, with a small increase between March 1996 and January 1997, and more substantial acceleration by May 1997. The next available interferogram, from January 1999, shows a well-developed area of accelerated flow covering $210 \mathrm{~km}^{2}$. This area increased to $550 \mathrm{~km}^{2}$ by January 2000, with maximum velocities of $>7 \mathrm{~m} \mathrm{~d}^{-1}$. The acceleration of flow coincided with a migration of the flow divide by about $16 \mathrm{~km}$ on the flat firn plateau, increasing the accumulation area.

The surge of Sylgjujökull was observed at its maximum and during its abating phase. The motion maps from December 1995 to October 1996 show high velocities at the terminus, with the velocity maximum close to the glacier front. The magnitude of ice motion decreased during this period by a factor of about two, but the extent of the area of accelerated flow did not change much. By December 1997, ice flow had decelerated significantly on the terminus, whereas the velocity in the central part of the glacier stayed about the same. ByJanuary 2000 the motion had come to an end almost all over the glacier.

The investigations indicate that one full surge cycle on 
these glaciers extends over a period of several years. The acceleration from the quiescent phase is very slow during the first year, but already extends over quite a large area. In the course of the surge, the velocity maximum migrates downglacier; on Dyngjujökull, the maximum velocity was located near the equilibrium line in January 1999 and near the snout in January 2000. The most active phase lasts for about 1 year. During the abating phase, which is at least four times longer than the most active phase, the motion at the terminus decelerates more rapidly than in the central part of the glacier.

For the surges of the two glaciers, ERS SAR interferometry provided significant information about the extent of the affected areas, including the migration of the flow divides, and about the temporal and spatial variations of the increased sliding after fieldwork became impossible.

\section{AGKNOWLEDGEMENTS}

The Austrian National Space Program, managed by the Austrian Space Agency, supported this work. ERS-1/-2 SAR data were made available by the European Space Agency for the projects AO.2-D116 (principal investigator (PI) U. Münzer), AO.3-239 (PI H. Rott) and AO.3-108 (PI D. Wingham). We thank two anonymous referees for their comments, which helped to improve the paper.

\section{REFERENGES}

Alsdorf, D. E. and L. G. Smith. 1999. Interferometric SAR observations of ice topography and velocity changes related to the 1996, Gjálp subglacial eruption, Iceland. Int. 7. Remote Sensing, 20(15-16), 3031-3050.

Björnsson, H. 1988. Hydrology of ice caps in volcanic regions. Reykjavík, University of Iceland, Societas Scientiarum Islandica. (Vísindafélag Íslendinga [Science in Iceland] 45.)

Björnsson, H. 1998. Hydrological characteristics of the drainage system beneath a surging glacier. Nature, 395(6704), 771-774.

Björnsson, H., F. Pálsson, M.T. Guðmundsson and H.H. Haraldsson. 1998. Mass balance of western and northern Vatnajökull, Iceland, 1991-1995. fökull, 45, 35-58.

Björnsson, H., H. Rott, S. Gudmundsson, A. Fischer, A. Siegel and M.T. Gudmundsson. 2001. Glacier-volcano interactions deduced by SAR interferometry. 7. Glaciol., 47(156), 58-70.

Björnsson, H., F. Pálsson, O. Sigurðsson and G. E. Flowers. 2003. Surges of glaciers in Iceland. Ann. Glaciol., 36, 82-90.

Fatland, D. R. 1998. Studies of Bagley Icefield during surge and Black Rapids Glacier, Alaska, using spaceborne SAR interferometry. (Ph.D. thesis, University of Alaska Fairbanks.)

Fatland, D. R. and C. S. Lingle. 1998. Analysis of the 1993-95 Bering Glacier (Alaska) surge using differential SAR interferometry. f. Glaciol., 44(148), $532-546$.

Gray, A. L., K. E. Mattar and N. Short. 2000. Speckle tracking for 2-dimensional ice motion studies in polar regions. In ESA Fringe'99 Meeting, 10-12 November 1999, Liège, Belgium. Proceedings. Noordwijk, European Space Agency, CD-ROM. (ESA Special Publication SP-478.)

Hanssen, R. 2001. Radar interferometry: data interpretation and error analysis. Dordrecht, Kluwer Academic Publishers.

Jónsson, S., N. Adam and H. Björnsson. 1998. Effects of subglacial geothermal activity observed by satellite radar interferometry. Geophys. Res. Lett., 25(7), 1059-1062.

Joughin, I., D. Winebrenner, M. Fahnestock, R. Kwok and W. Krabill. 1996a. Measurement of ice-sheet topography using satellite-radar interferometry. F. Glaciol., 42(140), 10-22.

Joughin, I., S. Tulaczyk, M. Fahnestock and R. Kwok. 1996b. A mini-surge on the Ryder Glacier, Greenland, observed by satellite radar interferometry. Science, 274(5285), 228-230.

Kamb, B. 1987. Glacier surge mechanism based on linked cavity configuration of the basal water conduit system. F. Geophys. Res., 92(B9), 9083-9100.

Massonnet, D. and K. L. Feigl. 1998. Radar interferometry and its application to changes in the Earth's surface. Rev. Geophys., 36(4), 441-500.

Paterson, W. S. B. 1994. The physics of glaciers. Third edition. Oxford, etc., Elsevier.

Raymond, C. F. 1987. How do glaciers surge? A review. 7. Geophys. Res., 92(B9), 9121-9134.

Rosen, P. A. and 6 others. 2000. Synthetic aperture radar interferometry. Proc. IEEE, 88(3), 333-385.

Rott, H. and A. Siegel. 1998. Interferometric analysis of surfaces in non-steady motion. In 2nd International Workshop on Retrieval of Bio- and Geo-physical Parameters from SAR Data for Land Applications, 21-23 October 1998, Noordwijk. Proceedings. Noordwijk, European Space Agency, 571-577. (ESA SP-406.)

Scharroo, R. and P.Visser. 1998. Precise orbit determination and gravity field improvement for the ERS satellites. 7. Geophys. Res., 103(C4), 8113-8127.

Strozzi, T., A. Luckman and T. Murray. 2000. The evolution of a glacier surge observed with the ERS satellites. In ERS-ENVISAT Symposium "Looking down to Earth in the New Millennium”, 16-20 October 2000, Gothenburg, Sweden. Proceedings. Noordwijk, European Space Agency, CD-ROM. (ESA SP-461.)

Thórarinsson, S. 1964. Sudden advance of Vatnajökull outlet glaciers 19301964. Jökull, 14, 76-89.

Thórarinsson, S. 1969. Glacier surges in Iceland with special reference to the surges of Brúarjökull. Can. F. Earth Sci., 6(4), Part 2, 875-882. 